\title{
Nouns as Lexical Heads in Urhobo English Code-Switching
}

\author{
Dr Fure Oduaran ${ }^{1}$ \\ ${ }^{1}$ English Dept. Delta State University, Abraka, Nigeria \\ Correspondence: Dr Fure Oduaran, English Dept. Delta State University, Abraka, Nigeria
}

Received: December 30, 2016

Accepted: January 27, 2017

Online Published: February 2, 2017

doi:10.5430/elr.v6n1p47

URL: http://dx.doi.org/10.5430/elr.v6n1p47

\begin{abstract}
Two topics in the front burner of contact linguistics are bilingualism and code switching. Code switching between an indigenous language and the English language is pervasive where outer circle Englishes are spoken. Nigeria and other former colonies of Great Britain belong to this circle of Englishes. This study discusses nouns functioning as lexical heads in Urhobo/ English code switches. The switches include code switched NP with determiners from Urhobo and head words from English; Urhobo -English complex Code switched NP with an adjective; complex CS NP with an adjective prepositional phrase as complement. The study is premised on two theories. First is Noam Chomsky's (1981) principles and parameters theory of transformational grammar which has been used for the analysis of the sentences. The second is Myers-Scotton's (2002) Matrix Language Frame (MLF), which is used for distinguishing between the matrix and the embedded languages in the nominal phrasal constituents within the code switched sentences. In this study, Urhobo is the matrix language while English is the embedded language based on matrix language frame (MLF) parameters. The study concludes that nouns functioning as lexical heads constitute part of the structural basis of Urhobo English code-switching.
\end{abstract}

Keywords: Nouns, Lexical Heads, Code Mixing, Code Switching Urhobo and English

\section{Introduction}

Languages have been in contact for over five hundred years (Crystal: 2000). This phenomenon has, however, become pervasive within the past century due to globalization. One of the linguistic outcomes of language contact is code mixing and code switching. Bullock and Toribio (2012: 1) highlight the importance of Code-Switching to contact linguistics when they observed that "of all the contact phenomenon of interest to researchers and students of bilingualism, code switching has arguably dominated the field". There are several definitions of code-switching and they revolve around the use of two or more languages within one or more utterances (Gardner-Chloros 2011; Poplack 1978/1981) Muysken 2005; Myers-Scotton (2002) and Borsley (2011). Contact linguists have also distinguished between code mixing and code switching. Muysken (2005: 1) defines code switching as "cases where lexical items and grammatical features of the two languages appear in one clause". Code switching according to Gardner- Chloros (2011) on the other hand "involves the use of two or more languages in the conversation of bilingual speakers".

This paper is a grammatical or structural approach to the analysis of nouns functioning as lexical heads in Urhobo-English code-switching. Urhobo is a South Western Edoid language spoken in the South-Western part of Niger Delta Region (Elugbe, 1991). Nigerian pidgin is a lingua franca in this region of the country. This pidgin creole (Bakker 2008) is usually code switched with about one hundred indigenous languages spoken in the Niger Delta region and English. Random language mixing between about twenty indigenous languages spoken in Delta State, English and Nigerian pidgin is a regular linguistic phenomenon.

The main objectives of this study include: providing an insight into the different approaches to code switching. Some of these are the grammatical or structural approach, the social and conversational approach and the psycho linguistic approach. The study briefly discusses the various types of heads in principles and parameters theory of Chomsky's transformational grammar. Finally the paper analyzes the determiner phrase where the noun functions as head and evaluates the satellites of the head in Urhobo/English code mixed structures.

\section{Theoretical Framework}

The theoretical framework for the code switched structures is Myers Scottons $(1993,2002)$ Matrix Language Frame (MLF). The theory states that in a piece of code switched discourse, the language with the highest number of 
morphemes is the matrix language. It adds that the matrix language supplies the system morphemes. Myer-scotton concludes that the embedded language contains constraints known as "embedded language Islands" which proves that code-switching is not a random phenomenon but a systematic one. X-Bar module of Chomsky's principles and parameters theory of transformational grammar is used for the analysis of the internal structure of the determiner Phrase (DP) within the noun functioning as the lexical head. The importance of the head in X-Bar syntax module where the head is projected and merged with specifier or complement based on projection principles, used for the deviation of phrases. Thus, the two theories aptly project the unique properties of nouns functioning as lexical heads in Urhobo English code switched variety.

\section{Data Collection Procedure}

The data for this study were collected mainly from Agbarho and Abraka in Urhobo land. Agbarho town is located in the central area. The standard dialect of Urhobo language is spoken in the Agbarho community. Abraka is the town where the main campus of the Delta State University is located. The resource persons from whom the data were collected are competent speakers of the standard dialect of Urhobo. They are either undergraduate students or holders of first degree certificates. They are balanced bilinguals. Sentence judgments were made by resource persons and the researcher, who is also an Urhobo and English balanced bilingual, in order to identify the grammaticality of the utterances. Questionnaires were administered on the resource persons to elicit information on important sociolinguistic status such as age, number of languages spoken, level of education and correctness of the code switched nouns and their satellites in the sentences. The quantitative method was adopted for data collection.

\section{Literature Review}

The study of language contact pioneered by Weinreich (1953/1968) spans several decades. All publications on bilingualism and code switching took cue from Weinreich publications. Pioneer linguists on code switching include; Labov (1972), Poplack (1978/1981) and Lance (1975). The seminal ideas of these linguists underscore the central role of code switching to bilingualism research. Many works on code switching have been published. Some prominent titles include Myers Scotton, C (1993) Dwelling Languages: Grammatical Structure in code switching, (2002) Contact linguistics Bilingual Encounters and Grammatical Outcome, Macswan, J_(1999)_A Minimalist Approach to Intra Sentential Code-Switching; Muysken, P. (2005) Billingual Speech: A Typology of code switching and Bullock, E and Toribo A.J. (2012) The Cambridge Handbook of Linguistics Code Switching.

The following are three perspectives to the study of code switching. They are Pragmatic/conversation analytic approaches, grammatical/structural approaches and the socio linguistics ethnographic description of code -switching. These three approaches foreground the complexity of code switching as a field of study in linguistics. The pragmatic/conversational approaches discuss how the language used by each of the interlocutors in code switched utterances influences the meaning of code swicthed Conservations. Myers- Scotton's (2002) "We code/they code" dichotomy aptly illustrates this dichotomy why 'we code' is the use of indigenous languages in Anglophone and Francophone African countries. 'They code' are ex-colonial languages like English and French which are elitist symbols. Thus, the elites of the society can engage in English/indigenous languages code- switching which the illiterates and semi-illiterates cannot linguistically engage. Myers-Scotton (200: 35) calls this phenomenon elite closure because it excludes the less educated members of the speech community from this linguistics repertoire, which is the linguistic preserve of the elite.

The grammatical approach to code-switching highlights the fact that code-switching is not a random linguistic phenomenon but a patterned one. Since this approach to code- switching is quite broad, three sub components have been identified. These are the production approaches, the variationist approaches, and the generative approach. The production approaches was initiated by Myer-Scotton (1993/2002). Two prominent theories of this approach are the "Matrix Language Frame' and 'Blocking Hypothesis". This approach dwells on the Psycho Linguistic aspect of code switching. The variationist approach which was popularized by Poplack (1980/1981) focuses on the linguistic universal constraint on code-switching. The bedrocks on which this approach to code switching hinges are: The "Free Morpheme Constraint" and "The equivalence Constraint". Chomsky (1999) is the theory on which the generative approaches hinge. Two constraints projected from this sub-type of grammatical approaches to code -switching include: "Functional Head Constraint" by Belazi, Robin and Toribo (1994) and Macswan (1999) and "Null Theory" which is based on the Minimalist Program. A peculiar feature of all the constraints mentioned above, is the fact that each of them has counter examples. This portrays the fluid nature of code switching. 


\section{Types of Heads in Code Switched Sentences}

In Chomsky's Principles and Parameters theory (1999) which is the theoretical framework for the grammatical analysis of nouns as lexical heads in this study, three types of heads have been identified. They are inflectional Head (INFL), Morpho-syntactic Head, and Lexical Heads. The three also constitute the input of analysis of heads in code switched utterances. Apart from Chomsky (1981), other renowned linguists that have discussed heads in syntax include Cowper (1992); Radford (1997). These syntacticians describe functional heads as form or grammatical words and affixes that are syntactic elements which serve as a frame for linguistic structure in a language. Functional heads have C-Commands a logical form between head and complement. A peculiar feature of functional heads is their scope of Morpho-Syntactic Heads. Morpho-syntactic heads are found mainly in complex words that have a free morpheme and one other are more bound morphemes. The bound morphemes are always suffixes and they function as the heads of morphological constituents. In such complex words, it is the suffix that determines the category realization of the word. In English, examples include class changing derivational morphemes.

\section{Class Changing Derivational Morphemes}

$\begin{array}{llll}\text { 1. } & \text { Free Morpheme } & \text { Suffix } & \text { Complex word } \\ \text { i. } & \text { Noun } & \text { Adj } & \text { Adj } \\ & \text { Nation } & \text {-al } & \text { national } \\ \text { ii. } & \text { Adj } & \text { Noun } & \text { Noun } \\ & \text { Fond } & \text {-ness } & \text { Fondness } \\ & & & \\ \text { iii. } & \text { Verb } & \text { Noun } & \text { Noun } \\ & \text { drive } & \text {-er } & \text { driver } \\ \text { iv. } & \text { Adj } & \text { Verb } & \text { Verb } \\ & \text { national } & \text {-ize } & \text { nationalize }\end{array}$

In (1i-iv) the morpho-syntactic heads are suffixes as diagrammatically illustrated with (1i and iii).
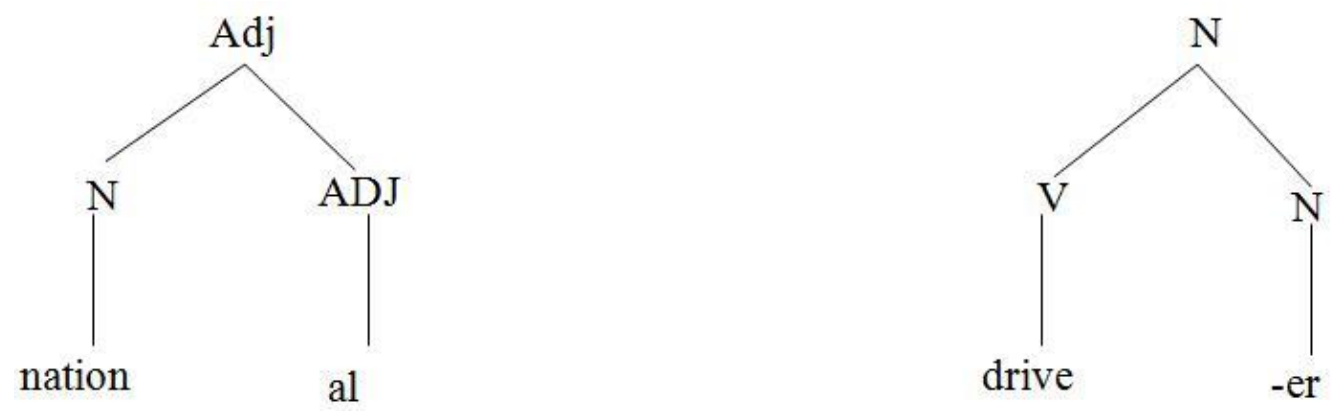

Thus, the morpho-syntactic heads in (1i and 1iii) are the suffixes which determine the complex words that are spread over any element in the clauses that they subcategorize. The functional heads identified by Radford (1997) and Chomsky and Lasnick (1995) are pronouns (he or she, I and you), possessives (its, their, his hers) determiners (the a/an) complements (that) agreement elements. It is pertinent to note that inflections (INFL) which are further split into tense, agreement and Negative also constitute functional heads. Chomsky (1999: 7) observes that "functional heads may have zero realization".

In Urhobo, functional heads include negative particles, focus, genitive topicalization and complementizers. Complementizers in Urhobo include né (that) rọ (who that which), examples derived through the morphological process of derivation.

In Urhobo, there are also morpho-syntactic heads. They include reduplication and prefixes that denote ownership. Unlike in English the Morpho-syntactic heads are prefixes. 


\section{1. i. Ógwì ímótó Ógwìmótó (driver) drives car ii. Ọ́shó ótó Óshótó (Land seller)}

\section{Lexical Heads}

Lexical heads are lexical itemS that function as heads of phrases. They include: nouns, adjectives, adverbs and verbs. The lexical head and its complement occur in the domain of functional head based on a sub categorization principle which Radford (1995: 365) defines as:

Any lexical item of category $x$ will be subcategorized with respect to the range of Idiosyncratic complement (i.e sister constituents) which permits within the minimal $x$-bar constituents in it.

\section{Nouns as Lexical Heads in Urhobo-English Code Switched Variety}

Since determiner phrases (DP) as well as all other phrases are endocentric constructions, all lexical words in the DP converge on the head N. Although it is the DP that serves as syntactic frame, nouns function as lexical heads within the frame and such nouns can be qualified by adjectives and other nouns. The main difference between Urhobo and English NP is the fact that the NP in Urhobo comes first while it is last in English.. The X-Bar module of the Principles and Parameters theory highlights the parametric differences between the two languages. The following examples highlight these differences.

\section{2i. English}

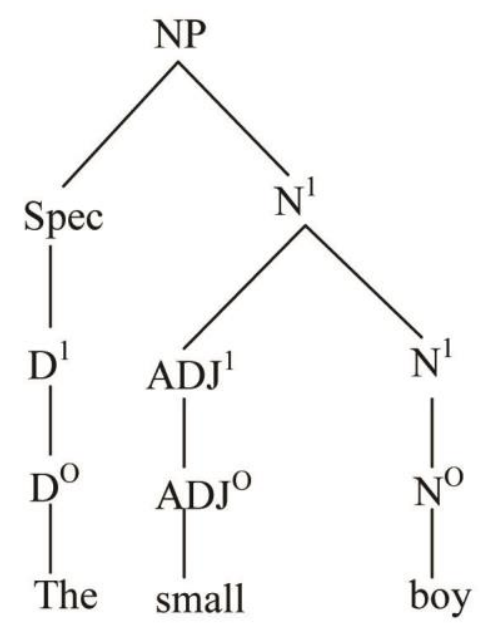

ii. Urhobo

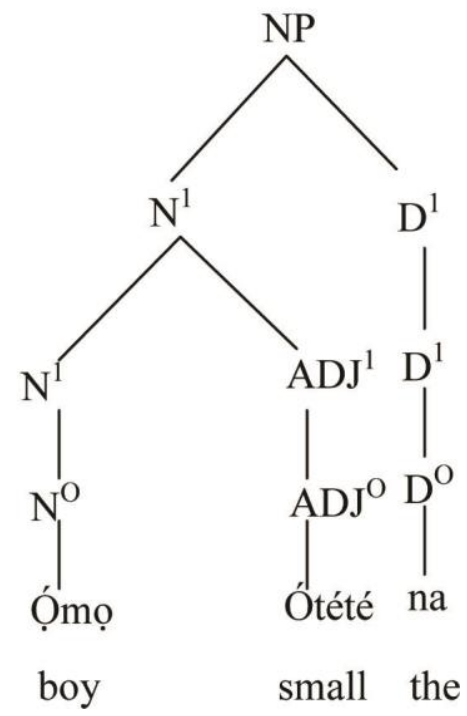

\section{Code Switched NP with Determiner from Urhobo and Head Word from English}

In a code switched nominal phrase that has a noun and a determiner, the head noun is usually from English which is the embedded language and the determiner or function morpheme is from Urhobo which is the Matrix language. The examples below instantiate the above.

3.

$\begin{array}{lll}\text { i. } & \begin{array}{c}\text { Bicycle náná } \\ \text { (Bicycle }\end{array} & \text { this) } \\ \text { ii. } & \text { Men } & \text { Yéná } \\ & \text { (Men } & \text { those) }\end{array}$

iii. Bucket nà
(bucket

iv. Brother mé

(Brother my) 
Below is a diagrammatic representation of (i) and (iv)

4.

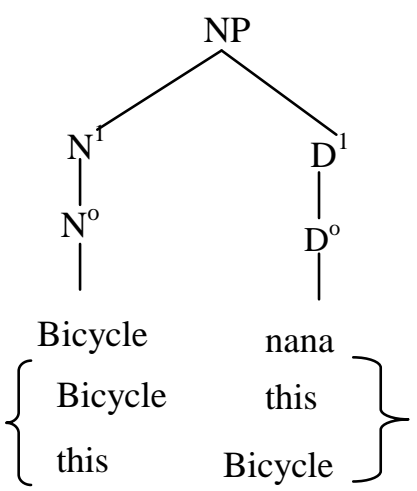

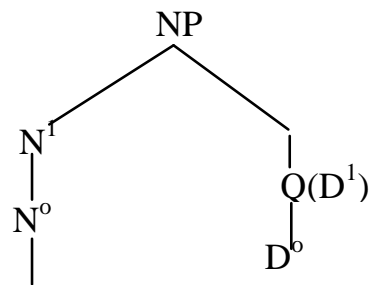

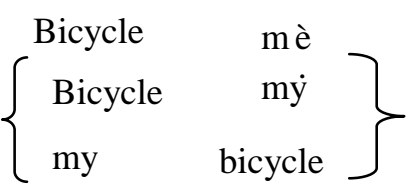

These nominal phrases are grammatical because they conform to Myers-Scotton's (2002) Matrix Language Frame (MLF) theory on the distribution of lexical and functional words in code switched structures. Myers-Scotton asserts that while lexical words are from the embedded language, in this case English. Functional words are usually from the matrix language (Urhobo).

Ungrammatical nominal phrases will evolve if the lexical noun head is from Urhobo and the function word is from English in the code switched nominal phrase above as shown below.

5 .
i. Ijíghéré this
(ii) Ésháré those
iii. Íkóróba the
(iv) Óniọvó my

The ungrammaticality of (5i-iv) is due to the violation of the distribution of lexical and function words in code switched structures in Myer Scotton MLF. All the NPs in (3i-iv) and (5i-iv) are head initial because in code switched structures, it is the matrix language that determines the structural pattern of a phrase or clause, and Urhobo, whose phrase are head initial, is the matrix language.

\section{Urhobo -English CS NPs with Genitives}

In CS complex NPs with genitives, the lexical head is usually from English, while the genitive can either be from English or Urhobo. Finally the determiner is usually from Urhobo as shown in the example below.

Only lexical head from English

\begin{tabular}{|c|c|c|c|}
\hline i. & Land óniọvó mè. & ii. & \\
\hline & Land brother my & & bucket mother my \\
\hline & My brother's land & & my mother bucket \\
\hline ii & mother émọ̀ mè. & iv & child ūgbéyàn mè. \\
\hline & Mother children my & & child friend my \\
\hline & My mother's children & & my friend's child \\
\hline
\end{tabular}

The two sets of examples above are grammatical; however ( $\mathrm{G}$ i \& ii) which is the first set of examples is more grammatically acceptable than the second set. Below are diagrammatic representations of both examples. 
8

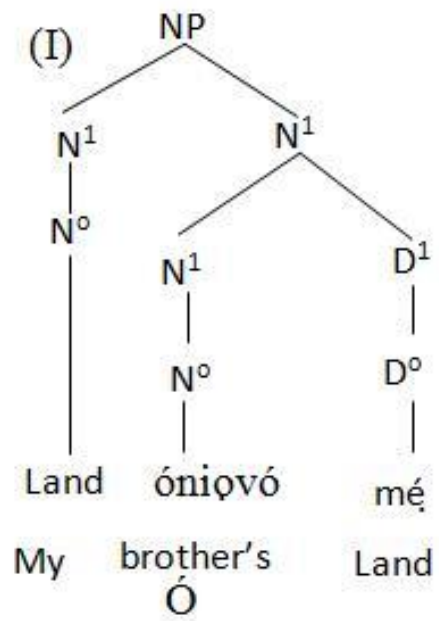

(II)

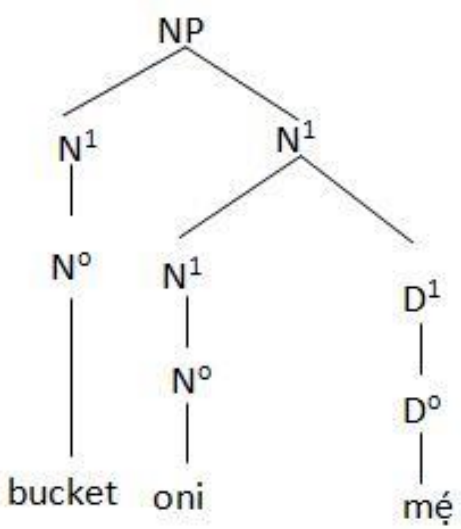

My Mother's bucket

These complex NPs with genitives have been made to conform to the structural pattern of Urhobo in two ways. First, the complex NPs are head initial. Second, Urhobo lacks the possessive markers ('S or S') as in English and they have been expunged since the structural pattern of the complex NPs above have to conform to that of Urhobo which is the Matrix language. If the English progressive marker is attached to the CS NPs genitive above, the structures will be ungrammatical since they have violated Urhobo structural pattern for genitives as shown below.
9.
i. Land óniovó's Me
ii bucket oni's mè.
My brother's land
my mother bucket

\section{Urhobo- English CS NPs with Adjectives}

Two types of Urhobo-English CS NPs with Adjectives are discussed in this section of the paper. First, are complex NPs with adjectives and numerical occurring in conjunction with the lexical head? Second, are complex Cs complex NP with a complex adjectival phrase that has intensifier as a specifier co-occurring with noun as the lexical head?

i. Picture Óbíébì ené

Picture black four

Four black picture

iii. bag íté té érhà

bag small three

Three small bags ii. Car kpókpò ívé

car new two

Two new cars

iv shirt ìgbégbé ésàn

shirt dirty six

Six dirty shirts

In the CS structures in (10 i - iv) above the lexical head is in English which is the embedded language while the adjective and numerical functioning as determiner are in Urhobo which is the matrix language. The CS complex NP is head initial in structure in conformity with the structural pattern of Urhobo (10 i and iv) are diagrammatically represented below. 

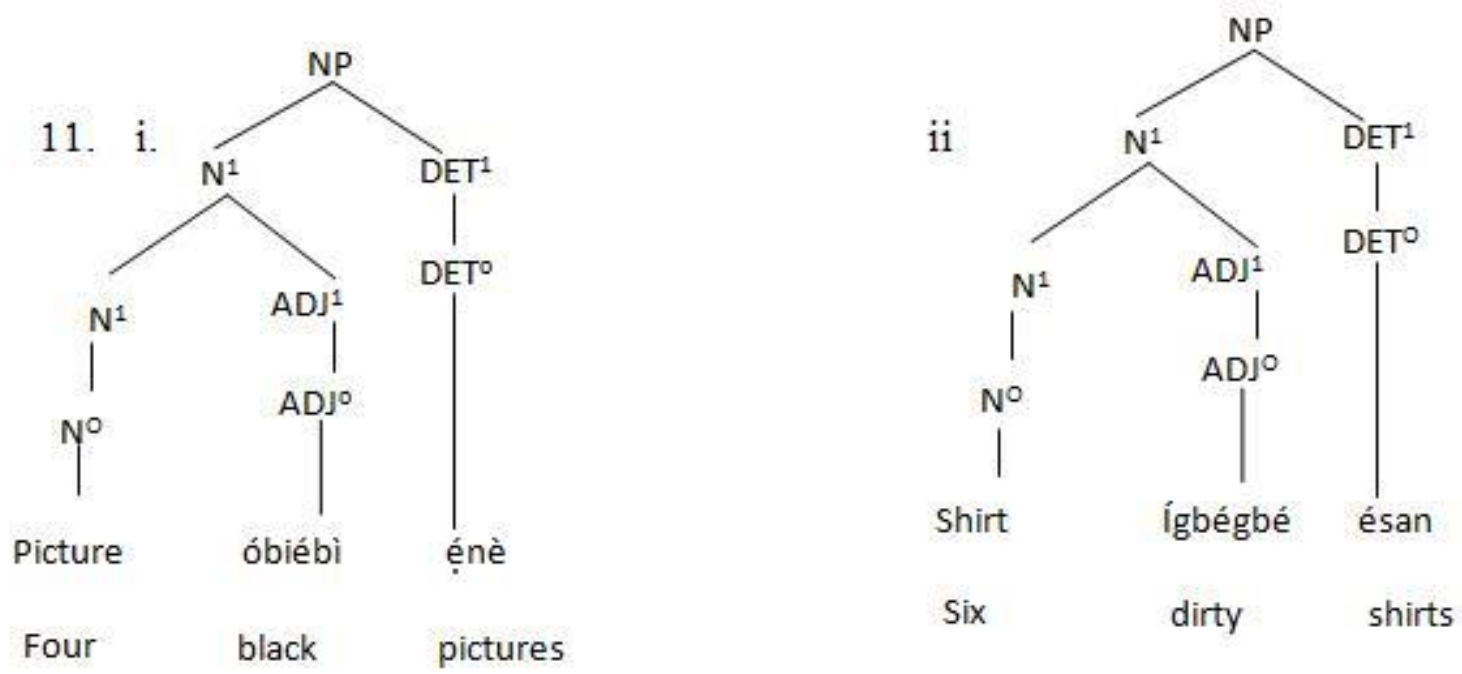

The complex NP code switched structure is ( ) will become ungrammatical if the head noun and the adjective are Urhobo and the numeral is in English as shown below:
12.(i) Ífótó óbíebí six
(ii) Ímótó kpókpo two
ii. ékpu ótété three
(iv) éwu ígbégbé six

The Ungrammaticality of the above complex NP Cs structures in (12 i-iv) is due to the fact that lexical words are supposed to be mostly from the embedded language while the function words like determiners are supposed to be derived from Urhobo which is the Matrix language. However, there is a reversal of lexical and function wordsabove since the lexical words are in Urhobo while the function word is in English.

\section{CS Complex NP with an Adjective and its Intensifier}

Example of CS Complex NP with an adjective and its intensifier are stated below.
13. i. Girl óbírí gángán
(ii) phone kpókpo gángán
(iii) Dog ộhórhó gángán
(iv) House ógbérí gángán

In (13 i-iv) the Lexical head is in English while the adjective and its intensifier is in Urhobo. The structural pattern of the complex NP is head initial which is in conformity with that of Urhobo, the matrix of language.

\section{Cs Complex NP with a Prepositional Phrase as Complement}

In CS complex NP with a prepositional phrase as complement, the lexical head of the NP and the noun functioning as the qualifier of the prepositional phrase are in English which is the embedded language while the preposition and the article functioning as the determiner are in Urhobo. Below are some examples.
14. i book énu table nà
Book top table the
The book on top of the table
ii Dog óbótọ motor nà
Dog under car the
The dog under the car
iii. Bread énu fridge nà
Bread on fridge the
The Bread on the fridge
iv shoe ótọ chair nà
Shoe bottom chair the
The shoe under the chair 
In (14 i-iv) above the lexical nouns are mainly in English while the function words are mainly in Urhobo in conformity with Myers Scotton's hypothesis in her MLF theory that function words are always mainly in the matrix language. (i and iv) and diagrammatically represented below:

15(i).

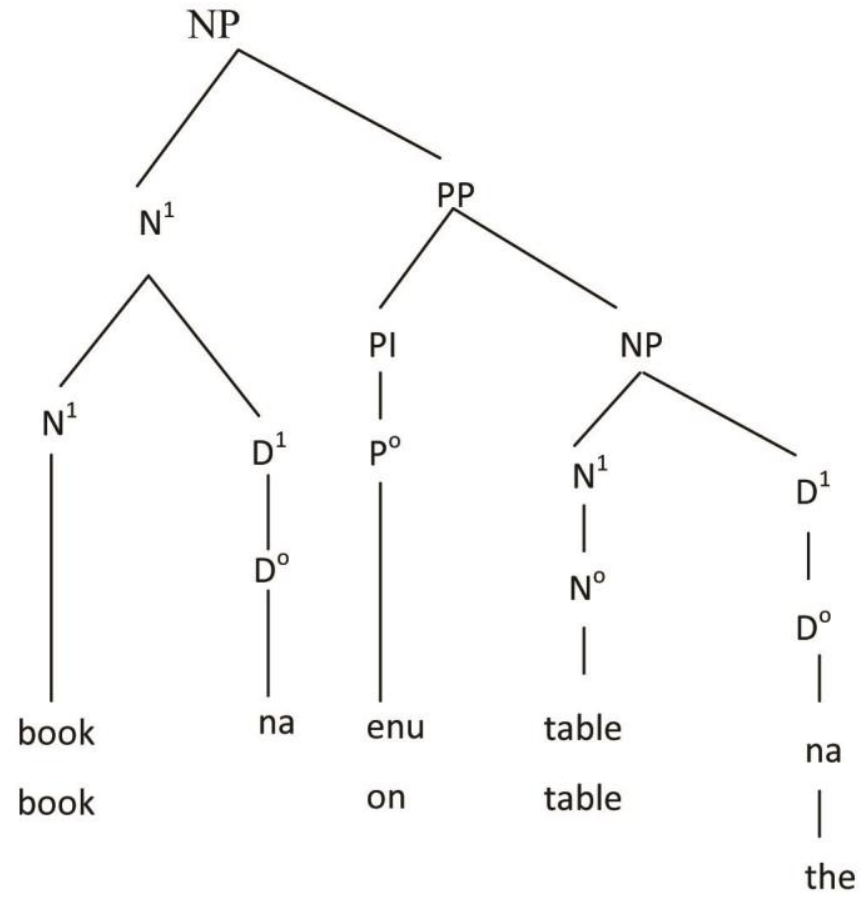

The

book on

the table

ii.

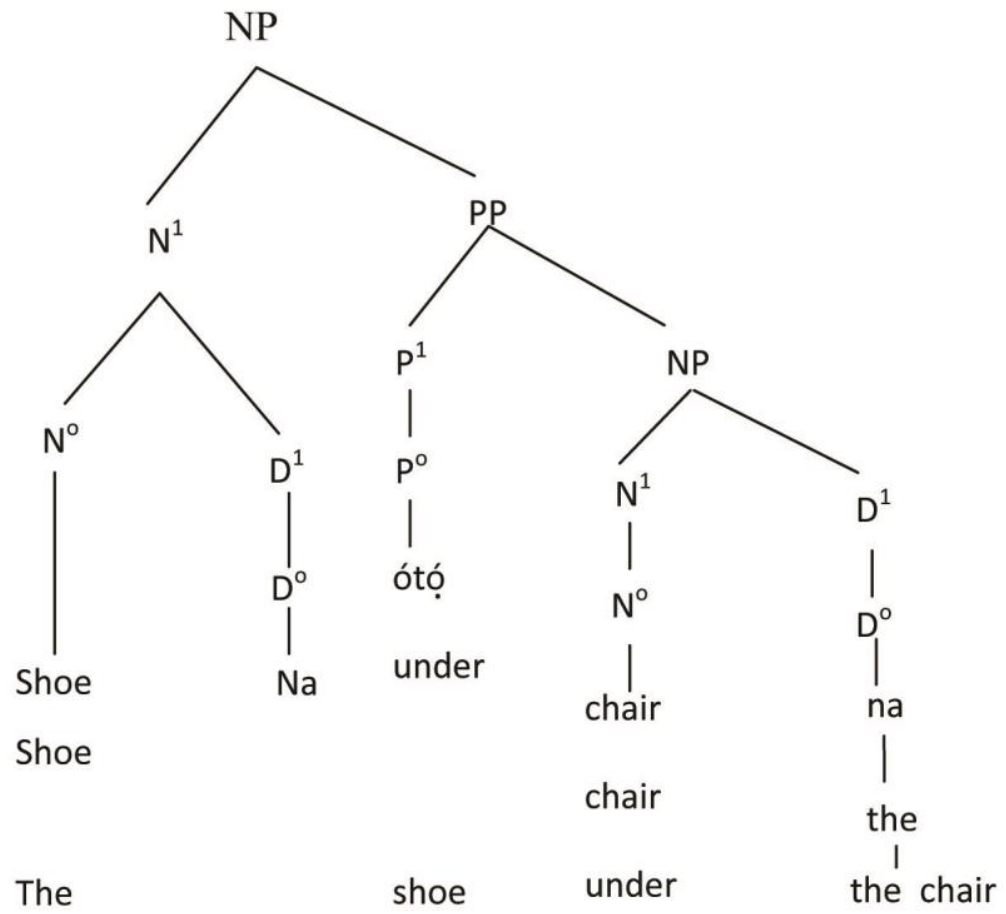

The complex NP CS structures in (15 i - ii) will be ungrammatical if the lexical nouns are in Urhobo and the function words, which are the preposition and the determiner, are in English. Below are examples. 
16i. Ejbe top ikpekpahen the

book top table the

The book on top of the table

ii. Erankon na under imoto the
dog

iii. Iburedi enu top ikpekpahen the

bread top table the

The bread on the table

iv. Isabato enu agbara the

shoe under chair the

The shoe under the chair

16. (i and iv) are diagrammatically represented below.

17.

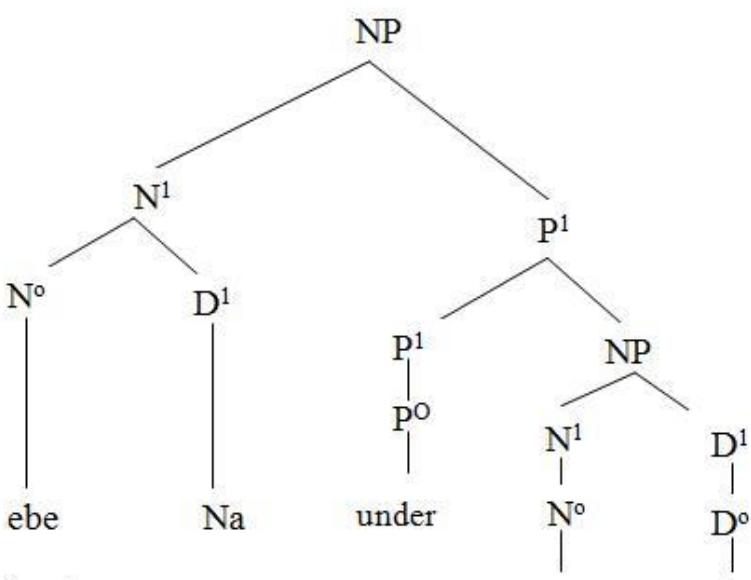

book under kpekpahen the

The book under the table

ii.

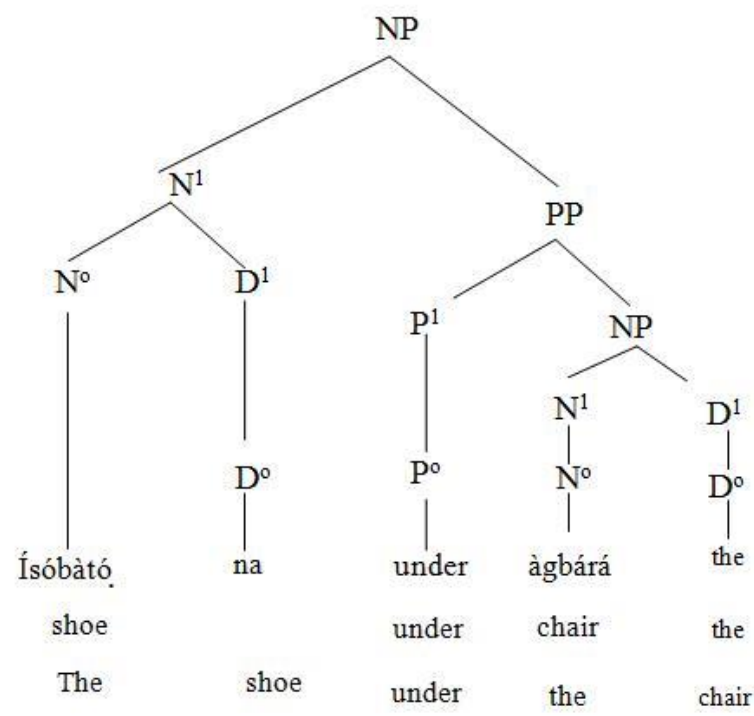




\section{Discussion and Findings}

From the sociolinguistic information obtained from the questionnaires administered on the resource persons, it was revealed that those engage in code-switching are predominantly youth and young adults. This buttresses Muysken (2005:213) assertion that code-switching is prevalent among youths. He concludes that code-switching decreases during adulthood. It was also observed that code-switching is regarded as an elitist symbol among the youths that engage in it because the linguistic phenomenon is a status symbol.

From the discussion on the grammaticality and ungrammaticality of CS complex noun phrases in Urhobo and English, we discovered that CS Urhobo - English NP head and its satellites are not haphazardly structured together; rather, they are systematic. However, the grammatical and acceptable structural patterns conform mainly to that of Urhobo nominal structure since it is the matrix language.

\section{Conclusion}

This essay has attempted to undertake a linguistic description of relationship between nouns as lexical heads and the relationship between the lexical heads and their satellites in Urhobo - English code switched variety. The paper buttresses Chloro's (2011) assertion that code switching is a creative exercise because this paper highlights the creativity of the resource persons who are able to sift out unacceptable ungrammatical CS NPs from the data collected. A salient issue in this study is the conformity of the structured patterns of the CS NPs with that of Urhobo which is the matrix language. Based on Myers - Scotton's MLF and 4-M models adopted for this study, Urhobo supplies the structured patterns and function words in the CS NPs. Finally, code-switching is a wide and largely unexplored field of research in the study of African languages. It is hoped that more linguists will engage in new researches in this semi-virgin research area.

\section{References}

Bakker, P (2008). Pidgins versus creoles and pidgin creoles (Eds) kouwenberg, S and J.V. The Handbook of Pidgin and Creole Studies. London U.K Wiley Blackwell (pp 130-157)

Belazi, H.M, Rubin, E.J \& Toribio, A.J. (1994). Code Switching and the X-Bar Theory: The Functional Head Constraint. Linguistic inquiry, 25(2), 221-37.

Bullock, E. \& Toribio, A.J. (2012). Themes in the study of Code Switching in Bullock, B.E and Toribio, A.J (Eds). The Cambridge Handbook of Linguistic code-switching. Cambridge: Cambridge University Press. $1-18$.

Borsley, R.D. (2011). Constructions, Functional Heads, and Comparative Correlatives. O. Bonami \& P. Cabredo Hofherr (eds.) In Empirical Issues in Syntax and Semantics, pp. 7-20

Chomsky, N. (1999). Derivation by Phrase. MIT Occasional Papers in Linguistics No. 18.

Chomsky, N \& Lasnik, H. (1995). The Theory of Principles and Parameters in Chomsky 1995, 13-127. Cambridge, M.A.M.I.T. Press.

Chomsky, N. (1986). Barriers. Cambridge, M.A.M.I.T. Press.

Cowper, G.A (1992). A Concise Introduction to Syntactic Theory Chicago. Chicago University Press.

Crystal, D (2000). Language Death. Cambridge, Cambridge University Press. https://doi.org/10.1017/cbo9781139106856

Elugbe, B. \& Omamor, (1991). Nigerian Pidgin (Background and Prospects), Ibadan, Heinemann Educational Books.

Gardner - Chloros, P. (2011). Code-Switching. Cambridge: Cambridge University Press.

Gumperz, J.J. (1976/1982). Conversational Code-Switching in J.J. Gumperz (Ed.) Discourse Strategies. Cambridge: Cambridge University Press.

Kageura, K. (2009). Computing the Potential Lexical Productivity of Head Elements in Nominal Compounds Using the Textual Corpus. Progress in Informatics, 6, 49-56. https://doi.org/10.2201/NiiPi.2009.6.6

Labor, W. (1972). Language in the Inner City. Philadelphia: University of Pennsylvania Press.

Lance D. (1975). Spanish - English code-switching in E. Hernandez - Chavez, A D Cohen, and A-F. Beltramo, (Eds) El Lenguaje de iso chicanos Washington Centre for applied linguistics, 138-53.

MacSwan, J. (1999). A Minimalist Approach to Intrasentential Code-Switching. New York: Garland Publishing Inc. 
Mesthrie, R. (Ed). (2011). The Cambridge handbook of Sociolinguistics. Cambridge: Cambridge University Press. https://doi.org/10.1017/CBO9780511997068

Muysken, P. (2005). Bilingual speech: A typology of Code-Switching. Cambridge: Cambridge University Press.

Muysken, P. (2008). Functional Categories. Cambridge: Cambridge University Press. https://doi.org/10.1017/CBO9780511755026

Myers - Scotton, C. (1976). Strategies of Neutrality Language Choice in Uncertain Situation" Language, 52, 919 41. https://doi.org/10.2307/413302

Myers - Scotton, C. (1993). Dwelling languages: Grammatical structure in code-switching. New York: Oxford University press.

Myers - Scotton, C. (2002). Contact Linguistics: Bilingual Encounters and Grammatical Outcomes. Oxford: Oxford University Press. https://doi.org/10.1093/acprof:oso/9780198299530.001.0001

Myers - Scotton, C. (2011). Code Switching in Mesthrie, R. (Ed). The Cambridge Handbook of Sociolinguistics. Cambridge: Cambridge University Press.

Poplack, S. (1978/81). Syntactic structure and Social Function of Code - Switching in R.P. Duran (Ed.), Latino Discourse and Communicative Behaviour. New Jersey Ablex Publishing Corporation. 169 - 84.

Radford, A. (1997a). Syntactic Structure and the Structure of English. Cambridge: Cambridge University press. https://doi.org/10.1017/CBO9781139166706

Weinreich, U. (1953/1968). Languages in Contact. The Hague. Mouton. 